\title{
Assessment of the Elderly and Their Caregivers' Knowledge Regarding Food Safety in Assiut Governorate
}

\author{
Hanan AbdAllah Abo-Zeid, Nazek Ibrahim Abd El-Ghany, Shokria Adly Labeeb , \& Safaa Rashad \\ Mahmoud.
}

Assistant lecturer, Geriatric Nursing, Faculty of Nursing, Assiut University

Professor of Community Health Nursing, Faculty of Nursing, Alexandria University

Professor of Community Health Nursing, Faculty of Nursing, Assiut University

Lecturer of Community Health Nursing, Faculty of Nursing, Assiut University

\begin{abstract}
:
Background: Food safety is an important part of public health that links health to agriculture and other food production sectors. Seniors are at particular risk of food borne illnesses because of their weaken immune systems, decrease in stomach acidity and intestinal peristalsis. The aim: to assess the knowledge of the elderly and their caregivers about food safety. Design: descriptive cross sectional research design. Setting: The present study was carried out at Assiut city and Assiut district in Assiut governorate. The subjects: purposive sample used in this study, $10 \%$ of the total number of the elderly people from every area was selected randomly who aged 60 years and above and their caregivers involved in the study. The total number of the elderly was 720 (340 from urban and 380 from rural areas) and their caregivers (135 subjects). Results: The results revealed that (44.1\%) of the urban and $(52.1 \%)$ of the rural elderly referred to the house wife as responsible for food safety, the majority of both the urban elderly $(85.0 \%)$ and their caregivers $(88.6 \%)$ identify the presence of different diseases caused by contaminated food. Conclusion: the subjects from both the elderly and their caregivers had a lack of knowledge regarding the non-recommended food for the elderly, pesticide residue elimination from the food. Recommendation: the information about food safety should be disseminated through mass media, television, newspapers and magazines at regular periods. Adequate books, periodical and pamphlets with simple explanations including materials related to food safety should be available in the different public libraries
\end{abstract}

Key words: food safety, food borne illness.

\section{Introduction:}

Food is a means to sustain and enjoy life but it is also a vehicle and a medium for transmitting hazards and causing disease and death. Planning an adequate diet does not only relate to nutritional adequacy and an individual's psychological and cultural needs but also to food quality and safety concerns (Dudek, 1997 and WHO, 2004).

The availability of safe food improves the health of people and is a basic human right. Safe food contributes to health and productivity. It provides an effective platform for development and poverty alleviation (WHO, 2002).

World Health Organization (WHO), Food, and Agriculture Organization (FAO) define food safety as food that is free from all hazards, whether chronic or acute that may make food injurious to the health of the consumer. Certain processes or handling practices by consumers in the home have been identified as being essential or critical in preventing food borne illness. These practices, which prevent or control the "dinner plate" microbial contamination, are associated with food borne illness, and under the direct control of the consumer from food acquisition through disposal. It includes purchasing, storing, preparing, cooking, serving, and handling leftovers (Worsfold \& Griffith, 1995, USDA, 1996 and WHO, 2004).

Food borne diseases are widespread and growing public health problem, both in developed and developing countries. The global incidence of food borne disease is difficult to estimate, but it has been reported that in (2005) alone 1.8 million people died from diarrheal diseases. A great proportion of these cases can be attributed to contamination of food and drinking water. In industrialized countries, the percentage of the population suffering from food borne diseases each year has been reported to be up to $30 \%$. In the United States of America (USA), for example, around 76 million cases of food borne diseases, resulting in 325,000 hospitalizations and 5,000 deaths, are estimated to occur each year (WHO, 2009).

Problems cited include emerging pathogens, improper food preparation, storage and distribution practices. There is an increase in the number of people at risk for food borne illness because of aging and compromised capacity to fight these diseases, very young, those who have an illness already that reduces their immune system function, and in healthy people exposed to a very high dose of an organism(FDA, 2002 and ADA, 2003). 
The great majority of the cases is mild and causes symptoms for only a day or two. Some cases are more serious; the most severe cases tend to occur in the old people who have more severe complications from food borne diseases, which lead to more hospitalizations and a higher death rate (FDA, 2002 and Yen, 2003). It affects from 60 to 80 million people worldwide each year (Perez, 2008).

With the aging process, inflammation of the lining of the stomach and a decrease in stomach acidity occurs. Because the stomach plays an important role in limiting the number of bacteria that enter the small intestine, a decrease or loss of stomach acidity increases the likelihood of infection if a pathogen ingested with food or water. Also adding to the problem is the slow down of the digestive process, allowing for the rapid growth of pathogens in the gut and the possible formation of toxins (Yen, 2003, CDC, 2004 and FDA, 2007).

The nurse can have a significant impact through health education. Most bacterial and viral food-borne diseases can be prevented if people know and practice proper cooking and storage of food as well as proper personal hygiene. Nurses can educate people to watch for signs of contamination. Nurses can raise public awareness regarding the conditions of supermarkets, restaurants, and other food handlers (Allender and Spradley, 2001).

Significance of the study:

Maintaining food safety in the homes of independently living elders can be a challenge. Diminished vision and sense of smell and taste, improper food handling and practice put the elders to increased risk of food-borne illness. Also because of their compromised immune status, conditions which are more common in older adults as diabetes mellitus, long steroid use for asthma or arthritis,.....etc and related drugs which are used compromise their immune system, making it more difficult for them to fight off infections (Insel et al., 2002).

Aim of the Study: To assess knowledge of the elderly and their caregivers about food safety and related food-borne illness.

Research questions:

1. What extent are the elderly and their caregivers knowledgeable about the meaning and responsibility of food safety?

2. What extent are the elderly and their caregivers knowledgeable about the diseases that caused by contaminated food, its symptoms and complication?

3. What extent are the elderly and their caregivers knowledgeable about the non recommended food for the elderly and elimination of pesticide residue?
4. What are the sources of information of the elderly and their caregivers regarding food safety?

\section{Subjects}

Setting: This study was carried out in Assiut city and Assiut district in Assiut Governorate (El-Hamarah Elaola, El-Waledya Elbahary, Elbesary and Elsharekat from Assiut city). (Sallam, Mankhabad, El-Zawya and Awlad Ibrahim from Assiut district).

Subject: Purposive sample was used in this study, the total number of elderly in year 2006 were (7271), $10 \%$ were taken randomly. The total number of the studied subjects were 720 elderly (340 from urban and 380 from rural areas) (aged 60 years and above), there were seven elderly were dropped out from the study and their caregivers (135 subjects) included in the studied subjects (35) from urban and (100) from rural.

Tool of the study: The tool was developed by (Jevsnik et. al., 2007) and modified by the researcher to obtain the necessary data. Content validity test was done through three experts from faculty of nursing staff. The interview sheet was done for both the elderly and their caregivers, it consist of two parts:

\section{(A) Socio- demographic data sheet:}

It elicits information about the age, sex, marital status, level of education, the job before retirement, residence ...etc.

(B) Assessment of the elderly and their caregivers' knowledge which include:

It entails (10) questions about food safety such as meaning of food safety, the responsibility of food safety, presence of diseases from the contaminated food, symptoms of these diseases and complications, the non recommended food for the elderly, ........etc.

Field work

The interview sheet was developed after reviewing the different related researches and literatures to collect the necessary data from the studied subject

Preparatory phase: The actual numbers of the elderly people in the previous mentioned areas and a permission to carry out this study were obtained.

Pilot study: A pilot study was conducted before starting of data collection, it was carried out on 20 subjects, which were excluded from the studied subject to confirm question clarity, and gauge likely interview duration.

Ethical considerations: Consent was taken from every participant, data was collected through interviewing the elders, and their caregivers individually, reassured that the information obtained will be confidentially, and used only for the purpose of the study.

Data collection: Collections of the data were done from January to May 2009 by the researcher and 
another two assistants who trained to collect the data and visited the selected houses, a systematic random sample approach was carried out to visit the selected houses(every fourth house was selected). The average time taken for completing each sheet was 15-20 minutes two days per week.

Statistical design: Data collected, coded, computerized, revised, categorized, tabulated and analyzed by using computer program SPSS "ver.17", using Chi-Square test to determine significance between non parametric data, using T-Test to determine significance for numeric data, it consider non significant when $\mathrm{P}>0.05$, it consider *significant when $\mathrm{P}<0.05$.

\section{Results:}

Table (1): Distribution of the studied (elderly and their caregivers) regarding their socio demographic characteristics.

\begin{tabular}{|c|c|c|c|c|c|c|c|c|c|}
\hline \multirow{3}{*}{ Items } & \multicolumn{4}{|c|}{ Elderly } & \multirow{3}{*}{ Items } & \multicolumn{4}{|c|}{ Care-givers } \\
\hline & \multicolumn{2}{|c|}{$\begin{array}{c}\text { Urban } \\
(\mathrm{N}=340)\end{array}$} & \multicolumn{2}{|c|}{$\begin{array}{c}\text { Rural } \\
(\mathbf{N}=\mathbf{3 8 0}) \\
\end{array}$} & & \multicolumn{2}{|c|}{$\begin{array}{l}\text { Urban } \\
(\mathrm{N}=35)\end{array}$} & \multicolumn{2}{|c|}{$\begin{array}{c}\text { Rural (N } \\
=100)\end{array}$} \\
\hline & No. & $\%$ & No. & $\%$ & & No. & $\%$ & No. & $\%$ \\
\hline $\begin{array}{l}\text { Age: } \\
\text { Mean age } \pm \text { SD }\end{array}$ & \multicolumn{4}{|c|}{$64.7 \pm 5.2$} & $\begin{array}{l}\text { Age: } \\
\text { Mean age } \pm \text { SD }\end{array}$ & \multicolumn{4}{|c|}{$30.0 \pm 7.9$} \\
\hline $\begin{array}{l}\text { Marital status: } \\
\text { - Single } \\
\text { - Married } \\
\text { - Widow } \\
\text { - Divorce }\end{array}$ & $\begin{array}{c}28 \\
169 \\
141 \\
2\end{array}$ & $\begin{array}{c}8.2 \\
49.7 \\
41.5 \\
0.6\end{array}$ & $\begin{array}{c}7 \\
215 \\
158 \\
0\end{array}$ & $\begin{array}{c}1.8 \\
56.6 \\
41.6 \\
0\end{array}$ & $\begin{array}{l}\text { Marital status: } \\
\text { - Single } \\
\text { - Married } \\
\text { - Widow } \\
\text { - Divorce }\end{array}$ & $\begin{array}{c}20 \\
15 \\
0 \\
0\end{array}$ & $\begin{array}{c}57.1 \\
42.9 \\
0 \\
0\end{array}$ & $\begin{array}{c}7 \\
93 \\
0 \\
0\end{array}$ & $\begin{array}{c}7.0 \\
93.0 \\
0 \\
0\end{array}$ \\
\hline $\begin{array}{l}\text { Educational } \\
\text { status: } \\
\text { - Illiterate } \\
\text { - Read and write } \\
\text { - Preparatory } \\
\text { - Secondary } \\
\text { - University } \\
\end{array}$ & $\begin{array}{c}194 \\
56 \\
19 \\
60 \\
11\end{array}$ & $\begin{array}{c}57.1 \\
16.5 \\
5.6 \\
17.6 \\
3.2 \\
\end{array}$ & $\begin{array}{c}319 \\
33 \\
8 \\
20 \\
0 \\
\end{array}$ & $\begin{array}{c}83.9 \\
8.7 \\
2.1 \\
5.3 \\
0 \\
\end{array}$ & $\begin{array}{l}\text { Educational } \\
\text { status: } \\
\text { - Illiterate } \\
\text { - Read and write } \\
\text { - Preparatory } \\
\text { - Secondary } \\
\text { - University } \\
\end{array}$ & $\begin{array}{c}0 \\
2 \\
18 \\
4 \\
11\end{array}$ & $\begin{array}{c}0 \\
5.7 \\
51.4 \\
11.4 \\
31.4\end{array}$ & $\begin{array}{l}51 \\
21 \\
20 \\
3 \\
5\end{array}$ & $\begin{array}{c}51.0 \\
21.0 \\
20.0 \\
3.0 \\
5.0\end{array}$ \\
\hline 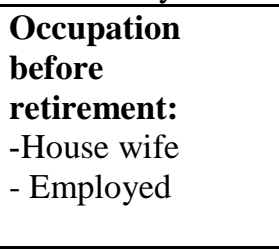 & $\begin{array}{l}312 \\
28\end{array}$ & $\begin{array}{c}91.8 \\
8.2\end{array}$ & $\begin{array}{c}340 \\
40\end{array}$ & $\begin{array}{l}89.5 \\
10.5\end{array}$ & $\begin{array}{ll}\begin{array}{l}\text { Relation to the } \\
\text { elderly: }\end{array} \\
-\quad \text { Daughter } \\
-\quad \text { Son's wife } \\
-\quad \begin{array}{l}\text { Other (son's } \\
\text { daughter) }\end{array} \\
\end{array}$ & $\begin{array}{c}11 \\
15 \\
9\end{array}$ & $\begin{array}{l}31.4 \\
42.9 \\
25.7\end{array}$ & $\begin{array}{c}7 \\
93 \\
0\end{array}$ & $\begin{array}{c}7.0 \\
93.0 \\
0\end{array}$ \\
\hline $\begin{array}{l}\text { Presence of care- } \\
\text { giver: } \\
\text { Yes } \\
\text { No }\end{array}$ & $\begin{array}{c}\mathbf{3 5} \\
305\end{array}$ & $\begin{array}{l}\mathbf{1 0 . 3} \\
89.7\end{array}$ & $\begin{array}{l}100 \\
280\end{array}$ & $\begin{array}{l}\mathbf{2 6 . 3} \\
73.7\end{array}$ & $\begin{array}{l}\text { Resident with } \\
\text { the elderly: } \\
\text { Yes } \\
\text { No }\end{array}$ & $\begin{array}{c}35 \\
0\end{array}$ & $\begin{array}{c}100 \\
0\end{array}$ & $\begin{array}{c}100 \\
0\end{array}$ & $\begin{array}{c}100 \\
0\end{array}$ \\
\hline
\end{tabular}

N.B.: all the studied subjects were females. 
Table (2): According to research question (No.1): Distribution of the studied subjects regarding their knowledge about food safety.

\begin{tabular}{|c|c|c|c|c|c|c|c|c|c|c|c|c|}
\hline \multirow[t]{3}{*}{ Items } & \multicolumn{6}{|c|}{ Elderly } & \multicolumn{6}{|c|}{ Care-givers } \\
\hline & \multicolumn{2}{|c|}{$\begin{array}{c}\text { Urban } \\
(\mathrm{N}=340)\end{array}$} & \multicolumn{2}{|c|}{$\begin{array}{c}\text { Rural } \\
(\mathbf{N}=380)\end{array}$} & \multirow[t]{2}{*}{ P-value } & \multirow[t]{2}{*}{$\mathbf{X}^{2}$} & \multicolumn{2}{|c|}{$\begin{array}{l}\text { Urban } \\
(\mathrm{N}=35)\end{array}$} & \multicolumn{2}{|c|}{$\begin{array}{c}\text { Rural } \\
(\mathrm{N}=\mathbf{1 0 0})\end{array}$} & \multirow[t]{2}{*}{ P-value } & \multirow[t]{2}{*}{$\mathbf{X}^{2}$} \\
\hline & No. & $\%$ & No. & $\%$ & & & No. & $\%$ & No. & $\%$ & & \\
\hline \multicolumn{13}{|c|}{ Meaning of food safety:\# } \\
\hline $\begin{array}{l}\text { a. Healthy and } \\
\text { valuable. }\end{array}$ & 3 & 0.9 & 0 & 0 & \multirow[t]{4}{*}{$\mathrm{p}<0.02 *$} & \multirow[t]{4}{*}{11.25} & 0 & 0 & 0 & 0 & \multirow[t]{4}{*}{$\mathrm{P}=0.001 *$} & \multirow[t]{4}{*}{14.83} \\
\hline b. Fresh food & 76 & 22.4 & 91 & 23.9 & & & 15 & 42.9 & 18 & 8.0 & & \\
\hline $\begin{array}{l}\text { C. not } \\
\text { contaminated. }\end{array}$ & 137 & 40.3 & 118 & 31.1 & & & 14 & 40.0 & 36 & 36.0 & & \\
\hline d. don't know & 127 & 37.4 & 171 & 45.0 & & & 6 & 17.1 & 46 & 46.0 & & \\
\hline \multicolumn{13}{|c|}{ Criteria of food safety:\# } \\
\hline Clean (hygienic) & 178 & 52.35 & 91 & 23.9 & \multirow{4}{*}{$\mathrm{p}<0.000^{*}$} & \multirow{4}{*}{21.48} & 10 & 28.6 & 2 & 2.0 & \multirow{4}{*}{$\mathrm{P}=0.000^{*}$} & \multirow{4}{*}{25.41} \\
\hline Fresh food & 119 & 35.0 & 68 & 17.9 & & & 17 & 48.6 & 14 & 14.0 & & \\
\hline $\begin{array}{l}\text { Good odor and } \\
\text { taste }\end{array}$ & 10 & 2.94 & 0 & 0 & & & 0 & 0 & 0 & 0 & & \\
\hline don't know & 63 & 18.5 & 221 & 58.2 & & & 8 & 22.9 & 84 & 84.0 & & \\
\hline \multicolumn{13}{|c|}{ The responsible for safety of food supply\# } \\
\hline Consumer & 55 & 16.2 & 10 & 2.6 & \multirow{7}{*}{$\mathrm{p}<0.000^{*}$} & \multirow{7}{*}{19.25} & 7 & 20.0 & 2 & 2.0 & \multirow{7}{*}{$\mathrm{P}=0.000^{*}$} & \multirow{7}{*}{17.42} \\
\hline Farmer & 19 & 5.6 & 0 & 0 & & & 0 & 0 & 0 & 0 & & \\
\hline Retailer & 63 & 18.5 & 79 & 20.8 & & & 0 & 0 & 81 & 81.0 & & \\
\hline $\begin{array}{l}\text { Ministry of } \\
\text { health }\end{array}$ & 33 & 9.7 & 57 & 15.0 & & & 4 & 11.4 & 2 & 2.0 & & \\
\hline Catering & 20 & 5.9 & 0 & 0 & & & 0 & 0 & 0 & 0 & & \\
\hline House wife & 150 & 44.1 & 198 & 52.1 & & & 28 & 80.0 & 17 & 17.0 & & \\
\hline don't know & 0 & 0 & 36 & 9.5 & & & 0 & 0 & 0 & 0 & & \\
\hline
\end{tabular}

\# More than one answer was allowed

*Significant

Table (3): According to research question (No.2): Distribution of the studied subjects regarding their knowledge about the diseases that caused by contaminated food.

\begin{tabular}{|c|c|c|c|c|c|c|c|c|c|c|c|c|}
\hline \multirow{3}{*}{ Items } & \multicolumn{6}{|c|}{ Elderly } & \multicolumn{6}{|c|}{ Care-givers } \\
\hline & \multicolumn{2}{|c|}{$\begin{array}{c}\begin{array}{c}\text { Urban } \\
(\mathrm{N}=\mathbf{3 4 0})\end{array} \\
\end{array}$} & \multicolumn{2}{|c|}{$\begin{array}{c}\text { Rural } \\
(\mathbf{N}=\mathbf{3 8 0})\end{array}$} & \multirow[t]{2}{*}{ P-value } & \multirow[t]{2}{*}{$\mathbf{X}^{2}$} & \multicolumn{2}{|c|}{$\begin{array}{l}\text { Urban } \\
(\mathrm{N}=35)\end{array}$} & \multicolumn{2}{|c|}{$\begin{array}{c}\text { Rural } \\
(\mathbf{N}=\mathbf{1 0 0})\end{array}$} & \multirow[t]{2}{*}{ P-value } & \multirow[t]{2}{*}{$\mathbf{X}^{2}$} \\
\hline & No & $\%$ & No & $\%$ & & & No & $\%$ & No & $\%$ & & \\
\hline \multicolumn{13}{|c|}{ Presence of diseases caused by contaminated food: } \\
\hline Yes & 289 & 85.0 & 237 & 62.4 & \multirow[t]{2}{*}{$\mathrm{p}<0.0^{*}$} & \multirow[t]{2}{*}{3.85} & 31 & 88.6 & 69 & 69.0 & \multirow{2}{*}{$\begin{array}{l}\mathrm{P}=0.00 \\
*\end{array}$} & \multirow[t]{2}{*}{12.92} \\
\hline No & 51 & 15.0 & 143 & 37.6 & & & 4 & 11.4 & 31 & 31.0 & & \\
\hline \multicolumn{13}{|c|}{ Type of the diseases \# } \\
\hline Gastroenteritis & 92 & 31.8 & 136 & 57.4 & \multirow{6}{*}{$\mathrm{p}<0.0^{*}$} & \multirow{6}{*}{17.82} & 27 & 87.1 & 68 & 98.6 & \multirow{6}{*}{$\begin{array}{l}\mathrm{P}=0.00 \\
*\end{array}$} & \multirow{6}{*}{3.92} \\
\hline Hepatitis (A). & 12 & 4.2 & 10 & 4.2 & & & 0 & 0 & 0 & 0 & & \\
\hline Dysentery & 4 & 1.4 & 26 & 11.0 & & & 0 & 0 & 54 & 78.3 & & \\
\hline $\begin{array}{l}\text { Parasitic } \\
\text { diseases }\end{array}$ & 7 & 2.4 & 20 & 8.4 & & & 0 & 0 & 54 & 78.3 & & \\
\hline food poisoning & 156 & 3.9 & 27 & 11.4 & & & 17 & 54.8 & 14 & 20.3 & & \\
\hline Do not know & 24 & 8.3 & 18 & 7.6 & & & 0 & 0 & 0 & 0 & & \\
\hline
\end{tabular}

\# More than one answer was allowed

*Significance 
Table (4) : According to research question (No.2): Distribution of the studied subjects regarding their knowledge about the diseases that caused by contaminated food.

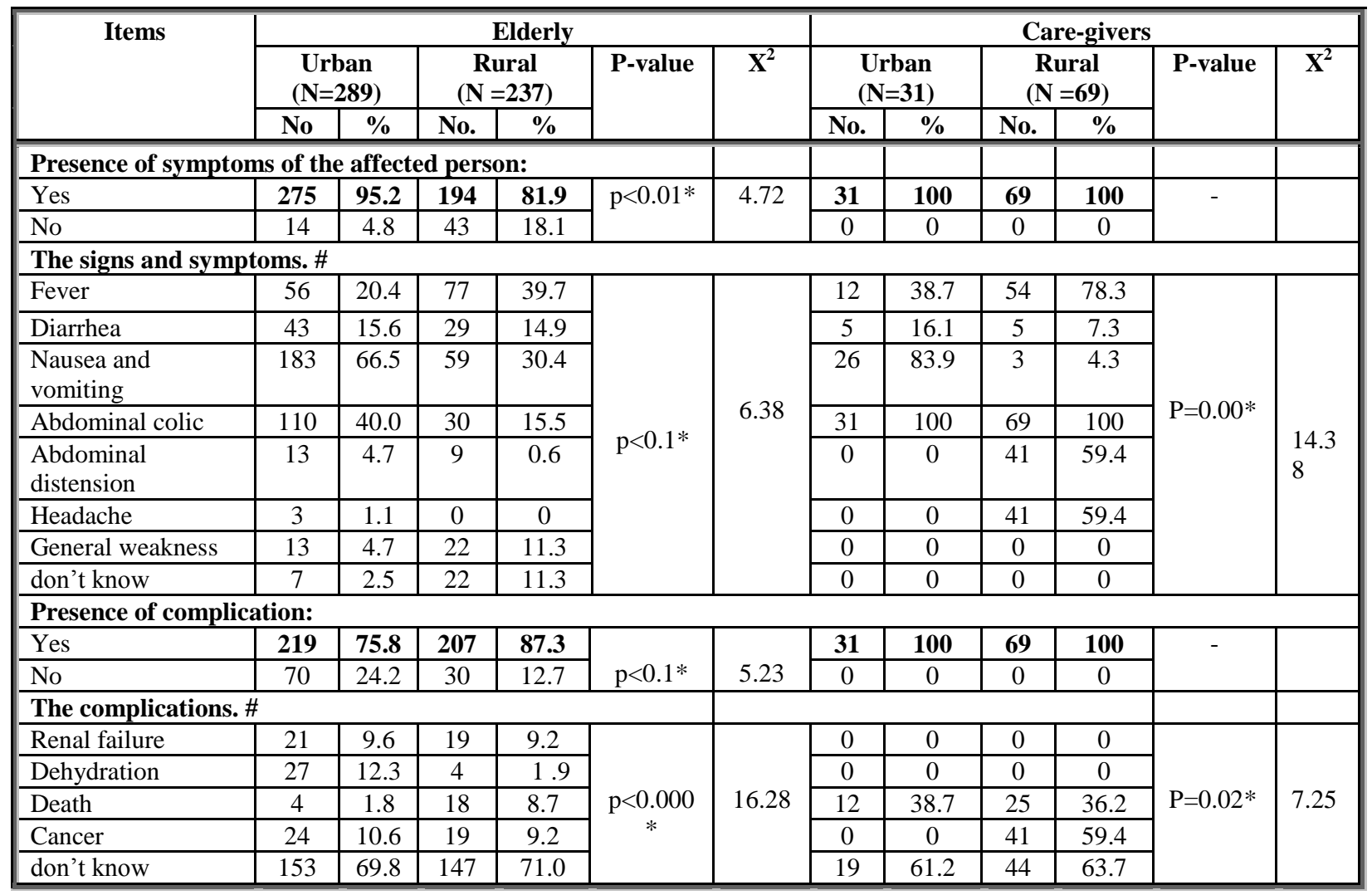

\# More than one answer was allowed

*Significant

Table (5) : According to research question (No.3): Distribution of the studied subjects regarding their knowledge about the non recommended food for the elderly.

\begin{tabular}{|c|c|c|c|c|c|c|c|c|c|c|c|c|}
\hline \multirow[t]{3}{*}{ Items } & \multicolumn{6}{|c|}{ Elderly } & \multicolumn{6}{|c|}{ Care-givers } \\
\hline & \multicolumn{2}{|c|}{$\begin{array}{c}\text { Urban } \\
(\mathrm{N}=\mathbf{3 4 0})\end{array}$} & \multicolumn{2}{|c|}{$\begin{array}{c}\text { Rural } \\
(\mathbf{N}=\mathbf{3 8 0})\end{array}$} & \multirow[t]{2}{*}{ P-value } & \multirow[t]{2}{*}{$\mathbf{X}^{2}$} & \multicolumn{2}{|c|}{$\begin{array}{l}\text { Urban } \\
(\mathrm{N}=35)\end{array}$} & \multicolumn{2}{|c|}{$\begin{array}{c}\text { Rural } \\
(\mathrm{N}=\mathbf{1 0 0})\end{array}$} & \multirow[t]{2}{*}{ P-value } & \multirow[t]{2}{*}{$\mathbf{X}^{2}$} \\
\hline & No. & $\%$ & No. & $\%$ & & & No. & $\%$ & No. & $\%$ & & \\
\hline \multicolumn{13}{|c|}{ Identify the presence of non recommended food for the elderly: } \\
\hline Yes & 251 & 73.8 & 187 & 49.2 & \multirow[t]{2}{*}{$\mathrm{p}<0.02^{*}$} & \multirow[t]{2}{*}{11.92} & 19 & 54.5 & 31 & 31.0 & \multirow[t]{2}{*}{$\mathrm{P}=0.007 *$} & \multirow[t]{2}{*}{6.85} \\
\hline No & 89 & 26.2 & 193 & 50.8 & & & 16 & 45.5 & 69 & 69.0 & & \\
\hline \multicolumn{13}{|c|}{ The non recommended food for the elderly:\# } \\
\hline None boiled milk. & 19 & 7.6 & 39 & 20.9 & \multirow{3}{*}{$\mathrm{p}<0.000 *$} & \multirow{3}{*}{22.38} & 0 & 0 & 0 & 0 & & \\
\hline $\begin{array}{l}\text { Others (salty, fatty and } \\
\text { high sugar food) }\end{array}$ & 182 & 72.5 & 50 & 26.7 & & & 19 & 100 & 31 & 100 & & \\
\hline Don't know & 63 & $25.1 \%$ & 101 & 53.9 & & & 0 & 0 & 0 & 0 & & \\
\hline
\end{tabular}

\# More than one answer was allowed

*Significant 
Table (6) : According to research question (No.3): Distribution of the studied subjects regarding their knowledge about pesticide elimination, the risks with the elderly.

\begin{tabular}{|c|c|c|c|c|c|c|c|c|c|c|c|c|}
\hline \multirow[t]{3}{*}{ Items } & \multicolumn{6}{|c|}{ Elderly } & \multicolumn{4}{|c|}{ Care-givers } & \multirow{3}{*}{ P-value } & \multirow{3}{*}{$\overline{\mathbf{X}^{2}}$} \\
\hline & \multicolumn{2}{|c|}{$\begin{array}{c}\text { Urban } \\
(\mathrm{N}=\mathbf{3 4 0})\end{array}$} & \multicolumn{2}{|c|}{$\begin{array}{c}\text { Rural } \\
(\mathbf{N}=\mathbf{3 8 0})\end{array}$} & \multirow[t]{2}{*}{ P-value } & \multirow[t]{2}{*}{$\mathbf{X}^{2}$} & \multicolumn{2}{|c|}{$\begin{array}{l}\text { Urban } \\
(\mathrm{N}=35)\end{array}$} & \multicolumn{2}{|c|}{$\begin{array}{c}\text { Rural } \\
(\mathbf{N}=\mathbf{1 0 0})\end{array}$} & & \\
\hline & No & $\%$ & No & $\%$ & & & No & $\%$ & No & $\%$ & & \\
\hline \multicolumn{13}{|c|}{ Pesticide residue elimination from fruits, vegetables and meat\# } \\
\hline $\begin{array}{l}\text { Washing } \\
\text { under } \\
\text { running } \\
\text { water }\end{array}$ & 119 & 35.0 & 74 & 19.5 & \multirow[t]{3}{*}{$\mathrm{p}<0.03 *$} & \multirow[t]{3}{*}{3.85} & 4 & 11.4 & 3 & 3.0 & \multirow[t]{3}{*}{$\mathrm{P}=0.089 \mathrm{n} . \mathrm{s}$} & \multirow[t]{3}{*}{0.241} \\
\hline $\begin{array}{l}\text { Washing in } \\
\text { basin }\end{array}$ & 213 & 62.7 & 222 & 58.4 & & & 31 & 88.6 & 97 & 97.0 & & \\
\hline Don't know & 10 & 2.9 & 84 & 22.1 & & & 0 & 0 & 0 & 0 & & \\
\hline \multicolumn{13}{|c|}{ Causes of the increased risk of this diseases with the elderly. \# } \\
\hline $\begin{array}{l}\text { Decreased } \\
\text { immunity }\end{array}$ & 146 & 42.9 & 112 & 29.5 & \multirow{5}{*}{$\mathrm{P}<0.000^{*}$} & \multirow{5}{*}{32.48} & 29 & 82.9 & 72 & 72.0 & \multirow{5}{*}{$\mathrm{P}=0.04 *$} & \multirow{5}{*}{3.85} \\
\hline $\begin{array}{l}\text { Diminished } \\
\text { taste, hearing } \\
\text { and vision } \\
\text { senses. }\end{array}$ & 25 & 7.4 & 29 & 7.6 & & & 0 & 0 & 0 & 0 & & \\
\hline $\begin{array}{l}\text { Inability to } \\
\text { meal } \\
\text { preparation }\end{array}$ & 122 & 35.9 & 19 & 5.0 & & & 12 & 34.3 & 42 & 42.0 & & \\
\hline $\begin{array}{l}\text { Chronic } \\
\text { diseases }\end{array}$ & 69 & 20.3 & 53 & 13.9 & & & 14 & 40.0 & 67 & 67.0 & & \\
\hline Don't know & 31 & 9.1 & 171 & 45.0 & & & 0 & 0 & 28 & 28.0 & & \\
\hline
\end{tabular}

\# More than one answer was allowed *Significant n.s.: not significant

Table (7) : According to research question (No.4): Distribution of the studied subjects regarding their sources of information about food safety.

\begin{tabular}{|c|c|c|c|c|c|c|c|c|c|c|c|c|}
\hline \multirow[t]{3}{*}{ Items } & \multicolumn{6}{|c|}{ Elderly } & \multicolumn{4}{|c|}{ Care-givers } & \multirow{3}{*}{ P-value } & \multirow{3}{*}{$\mathbf{X}^{2}$} \\
\hline & \multicolumn{2}{|c|}{$\begin{array}{c}\text { Urban } \\
(\mathrm{N}=340)\end{array}$} & \multicolumn{2}{|c|}{$\begin{array}{c}\text { Rural } \\
(\mathbf{N}=\mathbf{3 8 0})\end{array}$} & \multirow[t]{2}{*}{ P-value } & \multirow[t]{2}{*}{$\mathbf{X}^{2}$} & \multicolumn{2}{|c|}{$\begin{array}{c}\text { Urban } \\
(\mathrm{N}=35)\end{array}$} & \multicolumn{2}{|c|}{$\begin{array}{c}\text { Rural } \\
(\mathbf{N}=\mathbf{1 0 0})\end{array}$} & & \\
\hline & No. & $\%$ & No. & $\%$ & & & No. & $\%$ & No. & $\%$ & & \\
\hline \multicolumn{13}{|c|}{ The sources of food safety information\# } \\
\hline T.V. & 140 & 41.1 & 126 & 33.2 & \multirow{5}{*}{$\mathrm{P}<0.04^{*}$} & \multirow{5}{*}{6.29} & 27 & 77.1 & 95 & 95.0 & \multirow{5}{*}{$\mathrm{P}=0.01 *$} & \multirow{5}{*}{4.25} \\
\hline Books & 18 & 5.3 & 0 & 0 & & & 5 & 14.3 & 0 & 0 & & \\
\hline Doctors & 30 & 8.8 & 0 & 0 & & & 0 & 0 & 0 & 0 & & \\
\hline Radio & 15 & 4.4 & 48 & 12.6 & & & 0 & 0 & 42 & 42.0 & & \\
\hline Others (own experience) & 172 & 50.6 & 206 & 54.2 & & & 13 & 37.1 & 34 & 34.0 & & \\
\hline
\end{tabular}

\# More than one answer was allowed *Significant

Table (1) : describes the distribution of the studied subjects regarding their socio-demographic characteristics. It was observed that the mean age among the elderly was $(64.7 \pm 5.2)$ and $(30.0 \pm 7.9)$ among the caregivers, all the studied subjects (elderly and their caregivers) were females.

With regard to the educational status of the elderly, more than half $(57.1 \%)$ of the urban and the majority $(83.9 \%)$ of the rural elderly were illiterate, less than one-fifth $(17.6 \%)$ of the urban and only $(5.3 \%)$ from the rural had a secondary education.

Concerning the educational status of caregivers, more than half $(51 \%)$ of the rural and none of the urban were illiterate, while the university education was reported by less than one third $(31.4 \%)$ from the urban and only $(5 \%)$ of the rural caregivers.

Table (2) : illustrates the distribution of the studied subjects regarding definition, criteria and 
responsibility of food safety. It was observed that more than one third of the urban elderly $(37.4 \%)$ and more than two fifths of the rural elderly $(45 \%)$ did not know what is the meaning of food safety, while $(40.3 \%)$ and $(31.1 \%)$ of urban and rural elderly respectively reported that food safety means that food is not contaminated with microbes, the differences statistically were significant $(\mathrm{P}<0.02)$.

With regard to the caregivers, two fifths of the urban care givers $(40 \%)$ and more than one third $(36 \%)$ of rural caregivers stated that safety of the food means it is not contaminated with microbes. While less than one fifth of urban caregivers $(17.1 \%)$ and less than half of the rural caregivers $(46 \%)$ did not know the meaning of food safety, the differences statistically were significant $(\mathrm{P}=0.001)$.

Regarding the responsibility of the safety of food supply, more than two fifths of the urban (44\%) and more than half of the rural $(52.1 \%)$ referred to the house wife, around one fifth of both urban and rural elderly $(18.5 \%)$ and $(20.8 \%)$ respectively pointed to the retailer (seller) and only $(16.2 \%)$ and $(2.6 \%)$ respectively stated the consumer who is responsible for the safety of food supply, the differences statistically were significant $(\mathrm{P}<0.000)$. while the majority of the urban caregivers $(80 \%)$ and less than one fifth of the rural caregivers $(17 \%)$ referred to the house wife, the differences statistically were significant $(\mathrm{P}=0.000)$.

Table (3) : shows the distribution of the studied subjects regarding their knowledge about the diseases that can be caused by contaminated food, it was clear that the majority of the urban $(85 \%)$ and more than three fifths of the rural elderly $(62.4 \%)$ stated that there are different diseases can be caused by contaminated food $(\mathrm{P}<0.01)$. More than half of the urban elderly $(52.9 \%)$ and more than one tenth of the rural (11.4\%) stated food poisoning and less than one third of the urban $(31.8 \%)$ and more than half of the rural $(57.4 \%)$ reported gastroenteritis, the differences statistically were significant $(\mathrm{P}<0.000)$.

Concerning the caregivers, it is observed that the majority of the urban caregivers $(88.6 \%)$ and more than two thirds of the rural $(69 \%)$ reported that there are many diseases caused by food if it is contaminated ( $\mathrm{P}=0.007)$. The majority of the urban $(87.1 \%)$ and nearly all the rural caregivers $(98.6 \%)$ referred to gastroenteritis and more than half of the urban $(54.8 \%)$ and one fifth of the rural caregivers $(20.3 \%)$ reported food poisoning. The differences statistically were significant $(\mathrm{P}=0.000)$.

Table (4) : illustrates the distribution of the studied subjects regarding their knowledge about the signs and symptoms, and the complications of the diseases that can be caused by contaminated food. The vast majority of the urban elderly $(95.2 \%)$ and the majority of the rural $(81.9 \%)$ revealed the presence of symptoms with these diseases $(\mathrm{P}<0.01)$. Around one fifth of urban $(20.4 \%)$ and around two fifths of rural elderly (39.7\%) stated fever. Nausea and vomiting were reported by two thirds of the urban (66.5) and $(30.4 \%)$ of the rural. The differences statistically were significant $(\mathrm{P}<0.01)$.

With regard to the knowledge of the caregivers about the signs and symptoms, the entire participating subjects $(100 \%)$ in both urban and rural areas decided the presence of symptoms with the diseases that can be caused by contaminated food, all of them (100\%) reported abdominal colic. Less than two fifths of urban $(38.7 \%)$ and more than three quarters from the rural caregivers $(78.3 \%)$ stated fever. Most of the urban caregivers $(83.9 \%)$ and only $(4.3 \%)$ of rural caregivers reported nausea and vomiting, the differences statistically were significant $(\mathrm{P}<=0.000)$.

Table (5) : illustrates the distribution of the studied subjects regarding their knowledge about the non recommended food for the elderly, around three quarters of urban $(73.8 \%)$ and around half of the rural elderly $(49.2 \%)$ decided the presence of non recommended food for the elderly $(\mathrm{P}<0.02)$. The fatty, salty and high sugar foods reported by less than three quarters $(72.5 \%)$ of the urban and more than one quarter of the rural elderly $(26.7 \%)$, one quarter $(25.1 \%)$ of urban and more than one half $(53.9 \%)$ from the rural did not know exactly what it is, the differences statistically were significant $(\mathrm{P}<0.000)$.

Regarding the knowledge of the caregivers about the non recommended food for the elderly, more than half of the urban caregivers $(54.5 \%)$ and less than one third of rural $(31 \%)$ decided the presence of non recommended food for the elderly, the differences statistically were significant $(\mathrm{P}=0.007)$. All of them $(100 \%)$ in both areas pointed to salty, fatty and high sugar food.

Table (6) : illustrates the distribution of the studied subjects regarding their knowledge about the pesticide elimination from fruit, vegetables and meat, the causes that increase the risk of these diseases with the elderly. Regarding pesticide residue eliminate, it was observed that more than three fifths $(62.7 \%)$ of the urban and more than half of the rural $(58.4 \%)$ reported that washing fruits and vegetables in basin eliminates the pesticide residue, another $(35 \%)$ and $(19.5 \%)$ in both areas respectively reported washing fruits and vegetables under running water and more than one fifth of the rural $(22.1 \%)$ and $(2.9 \%)$ of urban did not know how they can eliminate pesticide residue from fruits, vegetables and meat, the differences statistically were significant $(\mathrm{P}<003)$.

Concerning the knowledge of the caregivers about the pesticide elimination from fruit, vegetables and meat, the vast majority of both urban and rural 
$(88.6 \%)$ and $(97 \%)$ respectively reported washing of fruits and vegetables in basin, the differences statistically were not significant $(\mathrm{P}=0.089)$.

Regarding their knowledge about the causes that increase the risks of these diseases among the elderly, more than two fifths of the urban elderly (42.9\%) compared to $(29.5 \%)$ from the rural stated the decreased immunity of the elderly people led to increasing the risk of these diseases.

Concerning the knowledge of the caregivers about their knowledge about the causes that increase the risks of these diseases among the elderly, the majority of the urban $(82.9 \%)$ and less than three quarters $(72 \%)$ of the rural caregivers reported the decreased immunity of the elderly people followed by chronic diseases reported by two fifths (40\%) of the urban and more than two thirds of the rural caregivers $(67 \%)$.

Table (7) : illustrates the distribution of the studied subjects regarding their sources of information about food safety. It was clear that more than half of both urban and rural elderly acquire their information from their own experiences $(50.6 \%)$ and (54.2\%) respectively. More than two fifths from urban $(41.1 \%)$ and one third of the rural $(33.2 \%)$ acquired their information from T.V., the differences statistically were significant $(\mathrm{P}<0.04)$.

Concerning the caregivers, more than three quarters of the urban $(77.1 \%$ ) had their information from T.V. and more than one third $(37.1 \%)$ of them had their information from their own experiences, while in the rural caregivers, the vast majority of them (95\%) had their information from T.V. and more than two fifths of them $(42 \%)$ had their information from radio and more than one third of them $(34 \%)$ reported that they acquired their information by their own experiences. The differences statistically were significant ( $P$ $=0.01)$.

\section{Discussions:}

Consumers differ in age, sex, culture, life experience, health, knowledge, nutritional needs, family status, purchasing power, occupation, education and access to the media, thus, their ideas of safe food will vary. The Academy of Microbiology has described safe food as the following: food is safe if properly handled at all steps of production, processing, distribution, retailing and food serving through consumption (WHO, 2004).

The food industry defines food safety by its specification for raw materials and finished products. These specifications define the acceptable limits for chemical hazards such as hormones and pesticides, physical hazards such as metal fragments, and microbiological hazards such as Salmonella and
Listeria (WHO, 2004).

In the present study, more than two fifths of the urban and three tenths of the rural elderly (table, 2) stated that the meaning of food safety as food that is not contaminated and more than one fifth of both urban and rural elderly stated fresh food respectively while among the caregivers more than one thirds of both urban and rural defined it as not contaminated food. This is due to the awareness of the public about food safety regardless the quality of the safety process.

In a study by (Willett, 2003) when asked who has the primary responsibility for safety of the food supply, nearly two fifths of the people surveyed thought government agencies e.g: FDA, USDA, and their inspectors should be primarily responsible for the safety of the public food supply, less than one third mentioned producer/ farmer and (9\%) mentioned processor /packager. In another study by (Jevsnik,et al., 2007), the consumers believed that they are not responsible for food safety to the same degree as food handlers(farmers, food industry, retailers, catering), they also believe that the Slovene Consumers' Association is not as strongly responsible as food handlers and other food safety institutions e.g: the Inspection and Ministry of Health.

All the previous studies are inconsistent with these findings, In the present study around half of both urban and rural elderly (table, 2) mentioned that the house wives are the primary responsible of food safety and around one fifth of them stated the retailer and a little of them stated Ministry of Health and the same opinion among the care givers, this is due to a decrease in the awareness of the public regarding the governmental role in food safety.

As regard to the diseases which are caused by contaminated food, the majority of both urban elderly and their caregivers (table, 3 ) stated the presence of diseases caused by contaminated food. Less than one third and most of both urban elderly and their caregivers stated gastroenteritis respectively and parasitic infestation was reported by few of urban elderly as well as few of rural elderly and more than three quarters of their caregivers respectively, these are the more common diseases caused by contaminated food. These finding are in agreement with another study conducted by (Abdel-Khalek, 2003) (conducted at the food serving places in Assiut University which involved all the food handlers) that revealed most of the respondents had knowledge about the presence of food borne diseases, more than one third of the respondents detected diarrhea as one of the food borne diseases and parasitic infestation was reported by few of the respondents, this indicating the awareness of the public about the presence of diseases caused by contaminating food. 
The presence of signs and symptoms reported by the majority of both urban and rural elderly in addition to the entire sample of caregivers (table, 4), this results is supported by (Fouda, 2000) in which more than three quarters of the studied sample knew the signs and symptoms of food poisoning from group 1 and group 2, (group 1 represented the mothers of children in centers affiliated to the Ministry of Social Affairs, group 2 represented the mothers of children in centers belonging to language school), this may be related to their experiences.

Concerning the symptoms of these diseases, the higher frequency for nausea and vomiting was among both of urban and rural elderly (table, 4). Fever was reported by one fifth and around two fifths among the urban and rural elderly respectively while among the care givers, fever mentioned by more than one third of the urban and more than three quarters of rural as a care givers, these symptoms are the most rapid and more common symptoms especially among children and in the rural areas, they gain their knowledge from these experiences.

As regard to the complications of these diseases, more than two-thirds of both the urban and the rural elderly (table, 4) identified the presence of complications and did not know these complications exactly; they might have reported this by guessing. All the studied caregivers in both urban and rural areas decided the presence of complications but more than three-fifths from urban and rural did not know exactly what it is. More than one-third of both stated death in sever cases, which may occur in some cases. Regarding the knowledge of the studied subjects of the non recommended food for the elderly, more than one quarter of the rural elderly and around three quarters of the urban elderly in addition to the entire sample of the caregivers(table, 5) stated that salty, fatty and high sugar food are the non recommended food for the elderly. This is related to the awareness of the public about the hazards of salts, fats and sugars for the elderly not the quality of the food.

To reduce the pesticide levels in the food, scrubbing all fruits and vegetables with water for at least 20 seconds, remove and discard the outer leaves of leafy vegetables, trim the fat from red meats, remove the skin and underlying fat from fish and poultry and discard the dripping and broths from animal products(Alters and Schiff, 2003).

Concerning their knowledge about the pesticide residue elimination from fruits, vegetables and meat, around three fifths of both urban and rural elderly(table 6) stated washing it in basin in addition to the vast majority of the caregivers of both urban and rural, this is the wrong practice, in the study by (Fouda, 2000) which demonstrated that more than one tenth of group 1 soaked vegetables and fruits in lemon or vinegar compared to more than one fifth of group 2, this reveals the awareness among the students and the teachers than the elderly people .

Regarding the sources of their information about food safety, more than half of both urban and rural elderly (table, 7) had their information from their own experiences and more than one-third of both urban and rural caregivers had their information from own experiences, so many practices were wrong and unsafe. Because T.V. is the more spread media in our communities nearly in all the houses, it is stated by more than two fifths and around one third of both urban and rural elderly respectively and most of and the vast majority of both urban and rural caregivers respectively, while in (Badrie et al., 2006) demonstrated that most consumers received information on food safety from television followed by newspapers (more than one half), radio (less than one half) and other such as magazines, internet and school stated by few of them. The results of (Willett, 2003) showed that T.V. news and advertisement were reported by more than one fifth of them, doctors reported by more than one tenth, less than one tenth of them by radio, around one fifth from friends and relatives, one fifth from books and more than one half from food label. It was observed that there are many different sources to gain their information about food safety.

\section{Conclusion and recommendations:}

The present study and research questions concluded that the studied subjects from both the elderly and their caregivers had a lack of knowledge regarding the responsibility of food safety, the nonrecommended food for the elderly, pesticide residue elimination from the food, the following recommendations could be made: adequate and variable books, periodical and pamphlets with simple explanations including materials related to food safety should be available in the different public libraries; information about food safety should be disseminated through mass media, T.V., newspapers and magazines at regular periods, designing food safety educational program directed to the general public with special emphasis on the high-risk groups as the elderly through mass media.

\section{References:}

1. Abdel Khalek, E.(2003): Assessment of food handling safety in Assiut University, master thesis, Faculty of Medicine, Assiut University.

2. American Dietetic Association (ADA) (2003): Position of the American Dietetic Association, food and water safety. Journal of ADA; 103(9).

3. Allender, J., and Spradley, B. (2001): Community health nursing, concept and practice. 
Promoting and protecting the health of older adult population. $5^{\text {th }}$ ed. Lippincott. New York.

4. Alters, S. and Schiff, W. (2003): Essential concepts for healthy living. Environmental health in and around the home. $3^{\text {rd }}$ ed. Jones and Bartlett publishers. London.

5. Badrie,N., Gobin, A., Dookeran, S., and Duncan, R. (2006): Consumer awareness and perception to food safety hazards in Trinidad, West Indies. Journal of food control; 17 (5).

6. Center for Disease Control and prevention (CDC) (2004): Diagnosis and management of food borne illnesses. A primer for physician and other health care professional. Morbidity mortality weekly report, 53(4).

7. Dudek, S. (1997): Nutrition handbook. Adult health issues and nutrition considerations for older adults. $3^{\text {rd }}$ ed. Lippincott. Philadelphia.

8. Food and Drug Administration (FDA) (2002): Can your kitchen pass the food safety test. Publication No. (2) -1229.

9. FDA, (2007): Senior and food safety. Why are seniors at risk for food borneillness?@http://www.fda.gov/downloads/F ood/ResourcesForYou/Consumers/Seniors/UCM 182784.pdf

10. Fouda, L. (2000): Role of mothers in providing safe food for their preschool children in Alexandria. Doctor thesis, High Institute of Public Health, Alexandria University

11. Insel, P., Turner, R. and Ross, D. (2002): Nutrition. Food safety and technology. Jones and Bartlett. London.

12. Jevsnik, M., Raspour, P. and Hlebec, V., (2007): Consumers' awareness of food safety from shopping to eating. Journal of food control; 07(017).

13. Perez, E.(2008): Food poisoning. Medline plus medical encyclopedia. 50(2).

14. United States Department of Agriculture (USDA)(1996): Consumer education and information. Food safety and inspection services (FSIS). Washington.@ www.fsis.usda.gov/oa/consedu.htm

15. World Health Organization (WHO) (2002): Food safety: a public health priority. Food safety department. Geneva, Switzerland.@ http://www.who.int/en

16. WHO (2004): Food safety: current situation, undressed issues and the emerging priorities. Eastern Mediterranean health journal; 10(6).

17. WHO (2009): Food safety and food borne illness. Fact sheet (237). Geneva, Switzerland.@ http://www.who.int/en
18. Willett,C.(2003): Attitudes toward agriculture and food safety among Missourians @ http://www.mda.mo.gov

19. Worsfold, D. and Griffith, C.(1995): A genetic model for evaluating consumer food safety behavior. Journal of Food control; 6 (6).

20. Yen, P. (2003): Nutrition and well-being. Preventing harm from food borne illness. Journal of Geriatric Nursing; 24(6). 